\title{
CONTINUATION OF A DECEDENT'S UNINCORPORATED BUSINESS IN PENNSYLVANIA
}

The owner of a business ${ }^{1}$ needs competent legal advice to determine the best of many alternatives to provide for the disposition of his business at his death. It is possible that he may not wish to have the business continue, but in all likelihood he will want to find a way to do so in order that his family can receive its full value if it is sold or its income if it is retained for the benefit of the family. One method, of course, is to leave it specifically to one or more beneficiaries. Another possibility, to avoid the legal problems arising from the death of the owner of a business, is incorporation. This not only insures that the death of the owner will not mean the termination of the business, but it also provides a relatively simple method for devolution of ownership through bequests of stock. In many cases, however, incorporation is not feasible and outright bequests do not promise to accomplish the testator's purpose. For this or other reasons, the owner of the business may ultimately direct that the business shall pass to his estate or to a trust to be continued in operation by the executor or a trustee. On the other hand, the owner may die without ever having made any provision for disposing of his business. In such cases the business becomes part of the estate. Much the same result will follow if the testator, probably as the result of a lack of proper advice, directs only that his business shall be continued without providing for the many practical and legal obstacles raised by such a bare general authorization to the personal representative.

Continuation of such a business may be desirable for several purposes. A sudden liquidation of a going concern cannot be consummated without substantial losses, especially if the business possesses a valuable good will or physical assets which ordinarily have little quick sale value. These losses would be avoided if the business could be continued so as to facilitate its sale as a going concern or its gradual liquidation. On the other hand, the beneficiaries of the estate, or some of them, may wish to continue the operation of the decedent's business indefinitely in order to receive the income that the continuing business will produce.

Without proper authority in the testator's will, however, the personal representative faces costly obstacles in serving the interests of the beneficiaries. By running the business without authorization of either will or court, he assumes the risk of surcharge for every loss incurred in the business. Even if the will gives a general power to continue the business, the trustee or executor may find that his discretion is highly restricted. Moreover, the beneficiaries face the risk of losing the assets of the entire estate to creditors of the business. Although these obstacles may be avoided in

1. Principal emphasis in this Note has been placed upon a study of the sole proprietorship. However, much of the discussion is relevant to partnerships and other forms of non-incorporated businesses. 
some states by obtaining the court's authorization to engage in transactions which may be necessary to operate the business to its greatest advantage, the risk of costly litigation which may restrict the powers of the trustee necessitates the drawing of a proper will provision.

The problem faced by the fiduciary under these circumstances is not peculiar to Pennsylvania, but in order to facilitate a more specific analysis of the problems which may arise and the methods by which they may be avoided, the discussion is largely restricted to that state.

\section{Right To Continue the Business}

Under the general rule in all jurisdictions, a fiduciary has no power to continue a decedent's business without authorization by will or court. ${ }^{2}$ Unauthorized continuation of a business by a fiduciary will subject him to the risk of surcharge for every loss incurred in the operation regardless of whether or not he was negligent $;^{3}$ conversely, any gain must be turned over to the estate. 4 Moreover, unauthorized continuation may constitute a breach of a fiduciary relationship in many respects such as the failure to maintain "legal" investments ${ }^{5}$ and the unauthorized use of trust funds. ${ }^{6}$ As a result, third persons dealing with the fiduciary may be unable to enforce their contracts against the estate. ${ }^{7}$

The Pennsylvania court has found justification for these harsh results in the fact that the representative may protect himself by selling the property rather than suffer any loss; if required to carry on the business or if its sale is impossible, the person nominated as executor or administrator may refuse to act as the personal representative. ${ }^{8}$ There are, however, exceptions to the rule which would indicate that its real basis is to enable creditors and beneficiaries to protect their interests from the risk of business failure whenever immediate sale is in any way a feasible alternative.

2. Theisen v. Hoey, 29 Del. Ch. 365, 51 A.2d 61 (Ch. 1947) ; Root's Estate v. Blackwood, 120 Ind. App. 545, 94 N.E.2d 489 (1950); In re Wolf's Estate, 87 N.Y.S. 2d 327 (Surr. Ct. 1943); Spivak v. Bronstein, 367 Pa. 70, 79 A.2d 205 (1951); see In re King's Estate, 19 Cal. 2d 354, 121 P.2d 716 (1942).

In the case of a partnership, the authority must be expressed in the articles of partnership. Brew v. Hastings, $196 \mathrm{~Pa} .222$, 46 Atl. 257 (1900); Gratz v. Bayard, 11 S. \& R. 41 (Pa. 1824); Jurkowitz v. Jurkowitz, 44 Lackawanna County Jurist 266 (Iackawanna County, Pa., C.P. 1943). See also cases cited in Fuller, Partnership Agreements for Continuation of an Enterprise After the Death of a Partner, 50 YALE L.J. 202, 205 (1940).

3. In re McGovern, 118 N.Y. Supp. 378 (Surr. Ct. 1908) ; Moran's Estate, $261 \mathrm{~Pa}$. 269, 104 Atl. 585 (1918).

4. Harrison v. Harrison, 39 Ala. 489 (1864) ; In re Byrnes, 114 App. Div. 532, 100 N.Y. Supp. 12 (1st Dep't 1906) ; Allam's Estate, 199 Pa. 573, 49 Atl. 252 (1901).

5. "Legal" investments are those approved by the courts as proper or prescribed by statutes. See, e.g., PA. Stat. ANn. tit. 20, $\$ \$ 320.506,320.821 .2-.9$ (Purdon 1950). Mattocks v. Moulton, 84 Me. 545, 24 Atl. 1004 (1892); In re Cady's Estate, 211 App. Div. 373, 207 N.Y. Supp. 385 (4th Dep't 1925) ; Nagle's Estate, $305 \mathrm{~Pa} 36,156$ Ati. 309 (1931).

6. Henchey v. Henchey, 167 Mass. 77, 44 N.E. 1075 (1896).

7. Lucht v. Behrens, 28 Ohio St. 231 (1876); Corr's Estate, 8 Pa. Dist. 209 (Philadelphia County Orphans Ct. 1899); McMahan v. Harbert, 35 Tex. 451 (1872); cf. In re Tisdale, 110 App. Div. 857, 97 N.Y. Supp. 494 (3d Dep't 1906).

8. See Nagle's Estate, 305 Pa. 36, 39, 156 At1. 309, 310 (1931). 
For example, the rule is not applicable if the interested parties consent to a continuation of the business, ${ }^{9}$ or if the only dissenting parties are creditors who are paid prior to its operation. ${ }^{10}$ If continuation in winding up the estate is necessary to avoid tremendous loss to the estate, the rule may not be applied, ${ }^{11}$ since in this case the interests of neither beneficiaries nor creditors are prejudiced. Where an executor could not sell real estate and standing timber without great loss, for example, the court sustained his action in milling the timber and continuing the business to dispose of it. ${ }^{12}$ In a few instances, the fiduciary's action has been upheld where the sale of the business was impossible. ${ }^{13}$ In Nagle's Estate, ${ }^{14}$ the fact that the life tenant refused to assent to the sale of the farm exonerated the trustee from liability for continuing to operate the farm.

The impracticability of relying on these exceptions to the rule in place of a proper testamentary disposition is readily apparent. Although continuation of the business may be advisable, the exact conditions under which the court would find the requisite danger of loss in immediate sale are uncertain. ${ }^{15}$ If the personal representative attempts to continue the business by obtaining the consent of creditors, he may find some reluctant to do so inasmuch as they will lose their priority over subsequent creditors. $^{16}$ Yet to make immediate payment may render the further operation of the business impossible. In addition to the reticence of the creditors to take the risk of allowing the business to continue there is the difficulty of obtaining the consent of all the beneficiaries. ${ }^{17}$ Even if this can be surmounted, long range planning necessary to effective operation of the business may be impossible since the beneficiaries probably may withdraw their consent at any time. ${ }^{18}$ Moreover, the tenuous legal status of the business presents a tremendous danger of time consuming and costly litigation.

9. Philco Radio \& Television Corp. v. Damsky, 250 App. Div. 485, 294 N.Y. Supp. 776 (2d Dep't 1937) ; Steeby v. Norcutt, 143 Ore. 501, 20 P.2d 1080 (1933); Estate of John S. Longnecker, 54 Dauphin County Rep. 24 (Dauphin County, Pa., C.P. 1943).

10. Willis v. Sharp, 115 N.Y. 396, 400, 22 N.E. 149, 150 (1889) (dictum).

11. See, e.g., Merritt v. Merritt, 62 Mo. 150 (1876) (hotel continued in operation to avoid loss in sale at auction); Greiner's Estate, $14 \mathrm{~Pa}$. Dist. 348 (Philadelphia County Orphans Ct. 1905) (retail liquor saloon; executor could not obtain buyer at private sale); Orne's Estate, 7 Pa. Dist. 337 (Philadelphia County Orphans Ct. 1898) (hosiery factory; could not obtain buyer except at great loss).

12. Benscoter Estate, 63 Pa. D. \& C. 543 (Luzerne County Orphans Ct. 1948).

13. Nagle's Estate, 305 Pa. 36, 156 Atl. 309 (1931) ; Greiner's Estate, 14 Pa. Dist. 348 (Philadelphia County Orphans Ct. 1905) ; Orne's Estate, 7 Pa. Dist. 337 (Philadelphia County Orphans Ct. 1898).

14. 305 Pa. 36, 156 At1. 309 (1931).

15. Compare Poullian v. Brown, 82 Ga. 412, 9 S.E. 1131 (1889), Succession of Sparrow, 39 La. Ann. 696, 2 So. 501 (1887), Florsheim Bros. v. Holt, 32 La. Ann. 133 (1880), with Lawton \& Willingham v. Fish, $51 \mathrm{Ga} .647$ (1873), Succession of Worley, 40 La. Ann. 622, 4 So. 570 (1888), Succession of Myrick, 38 La. Ann. 611 (1886).

16. See, e.g., Hicks v. Purvis, 208 N.C. 657, 182 S.E. 151 (1935); In the Matter of the Estate of A. C. Ennis, 96 Wash. 352, 165 Pac. 119 (1917).

17. See, e.g., Nagle's Estate, 305 Pa. 36, 156 Atl. 309 (1931).

18. This rule would appear to be obvious, but there are no cases directly in point. Cf. Parry's Estate, 244 Pa. 93, 90 Atl. 443 (1914) (trustee surcharged even though consent to run the business had been given by the beneficiaries, but the trustee went beyond their consent in his actions). 


\section{General Authorization by WILL}

A testamentary provision which gives the personal representative or a trustee a general authorization to continue any business owned by the testator at his death is only a partial solution to the problem. Although this may give the fiduciary the power to continue the business indefinitely, ${ }^{19}$ the failure to specify the powers which may be exercised in its operation places an impractical limitation on the fiduciary's exercise of discretion. The delegation of many business decisions, which in many cases is a necessary procedure, may be impossible. His investments are subject to attack, and his power to use any other part of the estate in the business is limited. Moreover, his ability to use the principal of the entire estate in the business may result in subjecting all the assets of the estate to the rights of creditors of the business with a total loss to the beneficiaries.

\section{Delegation of Authority}

The Pennsylvania courts have said consistently that ". . . in determining what acts may be validly delegated and what may not, a distinction is made between discretionary acts and ministerial acts, the general rule being that the former may not be delegated, while the latter may. . . "20 Many problems arise in the application of such a rule. The major dilemma facing any fiduciary is how to distinguish a ministerial duty from a discretionary act. There is no doubt that a trust company may assign various duties to its own employees, ${ }^{21}$ but beyond this any attempt at delegation is fraught with danger of over stepping the bounds of the rule. It has been held that the duty to collect and deposit money can be delegated where there is no reason to suspect the honesty of the person so designated, ${ }^{22}$ but the courts have consistently struck down any attempt by a fiduciary to delegate the power to invest, ${ }^{23}$ or the power to close a sale without reporting the offer to the fiduciary and securing his approval, ${ }^{24}$ or the power to determine what share of income shall be paid to the beneficiary where the controlling instrument vests that determination in the fiduciary. ${ }^{25}$

In the conduct of an ordinary business it would seem necessary to give the fiduciary substantial powers of delegation in the every day operation of

19. Conant v. Blount, 141 Fla. 27, 192 So. 481 (1939); cf. Foxworth v. White, 72 Ala. 224 (1882); In re King's Estate, 19 Cal. 2d 354, 121 'P.2d 716 (1942); Willis v. Sharp, 115 N.Y. 396, 22 N.E. 149 (1889); Spivak v. Bronstein, 367 Pa. 70, 79 A.2d 205 (1951).

20. Herr v; United States Casualty Co., $347 \mathrm{~Pa} .148,150,31$ A.2d 533, 534 (1943); see also Bohlen's Estate, $75 \mathrm{~Pa} .304$ (1874).

21. See, e.g. Stockwell v. Barnum, 7 Cal. App. 413, 94 Pac. 400 (1908); Chicago Title \& Trust Co. v. Zinser, 264 I11. 31, 105 N.E. 718 (1914); 2 Scorr, Trusis 917-18 (1930).

22. Herr v. United States Casualty Co., $347 \mathrm{~Pa} .148,31$ A.2d 533 (1943).

23. Iscovitz's Estate, 319 Pa. 277, 179 Atl. 548 (1935); cf. Kohler's Estate, 348 Pa. 55, 33 A.2d 920 (1943).

24. See Graham v. King, 50 Mo. 22 (1872); Bohlen's Estate, 75 Pa. 304 (1874).

25. Matter of Osborn, 252 App. Div. 438, 299 N.Y. Supp. 593 (2d Dep't 1937). 
the business. Reflective of this is the fact that trust companies, given the responsibility of continuing a decedent's business, wish to and do retain key employees in order to insure proper functioning of the business. ${ }^{26}$ In most businesses there is a need for specialized knowledge which the fiduciary cannot be expected to have. For example, the day to day purchase of inventory may require specialized knowledge, but under a literal reading of the cases, this may be an undelegable investment since it is of a discretionary nature. ${ }^{27}$

The sparcity of cases in the context of continuing a decedent's business as related to the extent of legally permissive delegation makes it difficult to determine whether or not the courts would allow some functions to be delegated even though not within the category of ministerial acts. The testator's general authorization to continue the business may imply a power to delegate some discretionary acts, but such an implication would be so dependent on the facts of each case that the trustee would be forced to act with undue restraint. A better rule of law might be to test the permissibility of delegation in accordance with the usual business practice among ordinary prudent business men managing property to achieve a constant flow of income and conservation of capital funds. ${ }^{28}$ Although this might enable the fiduciary to act more freely, the risk of surcharge arising from delegations improper under even a more liberal standard than is presently found may deter him from delegating functions which might be performed more profitably by others.

\section{Investments of Capital}

Under the Fiduciaries Investment Act of $1949,{ }^{29}$ the investments by a fiduciary are limited to investments such as state and federal obligations, ${ }^{30}$ certain corporate bonds, ${ }^{31}$ mortgages, ${ }^{32}$ stocks with prescribed dividend and earnings records ${ }^{33}$ and real estate located in Pennsylvania. ${ }^{34}$ Clearly this does not include investments necessary to the operation of the ordinary commercial business such as the purchase of inventory. However, the act specifically states that the directions of the testator, as to the type of investments allowed, control. ${ }^{35}$ "Non-legal" investments also may be made if (1954).

26. See Pfleiderer, When the Fiduciary Takes Over, 93 Trusts \& Estates 107

27. Cf. Stong's Estate, 160 Pa. 13, 28 Atl. 480 (1894); Woddrop v. Weed, 154 Pa. 307, 26 Atl. 375 (1893).

28. See BogerT, Trusts 383 (3d ed. 1952).

29. Pa. Stat. Ann. tit. 20, $\S 8$ 821.1-.22 (Purdon Supp. 1954).

30. $I d . \S 821.3$.

31. Id. $\$ 821.6$.

32. $I d . \S 821.7$.

33. $I d . \S 821.9$.

34. Id. $\$ 821.10$.

35. Id. $\$ 821.18$, Carr Estate, 355 Pa. 438, 50 A.2d 330 (1947). 
these is acquiescence of the beneficiaries ${ }^{36}$ or permitted by the terms of a court order. 37

The effect of a bare general authorization to continue the business in removing limitations on the power to invest is uncertain since no decisions have been made directly on this point. Perhaps the problem is one of construing the testator's intent and the nature of his business. If it is found that he intended the business to be continued only for purposes of liquidation, investments in new inventory might not be allowable. On the other hand, if it was intended that it be continued for purposes of resale as a going concern, or to produce income for the beneficiaries, there would be little problem in investing it in inventory. However, if the business is to be operated only for sale as a going concern, the purchase of capital items such as buildings or equipment might subject the fiduciary to surcharge. ${ }^{38}$ This principle of construing the power to invest to accord with the findings of the testator's intent is probably subject to the limitation that investments can be made only to continue the same business as was operated by the testator. An attempt to branch out into a new line of business would probably be an illegal investment. ${ }^{39}$

\section{Sources of Capital}

The cases which have arisen from continuation of decedents' businesses frequently have been concerned with the trustee's power to take additional capital out of the other principal of the estate for investment in the decedent's business. In the ordinary conduct of a business, the entrepreneur is often faced with a shortage of working capital. To meet expenses, to make necessary expansions and for many other purposes, new capital may be necessary. A general authorization in the testator's will to continue the business enables the fiduciary to invest other principal of the estate in the

36. Clabby's Estate, 338 Pa. 305, 12 A.2d 71 (1940); Detre's Estate, 273 Pa. 341, 117 At1. 54 (1922).

37. Riebel's Estate, $321 \mathrm{~Pa} .145,184$ Atl. 118 (1936).

38. Cf. In re Tisdale, 110 App. Div. 857, 97 N.Y. Supp. 494 (3d Dep't 1906); Parry's Estate, 244 Pa. 93, 90 Atl. 443 (1914).

39. Cf. Butler v. Butler, 164 IIl. 171, 45 N.E. 426 (1896); BogerT, Trusts 531 (3d ed. 1952). In addition to the possible ameliorating effect on the strict doctrine of surcharging a fiduciary for making unauthorized investments that might be derived from the testator's general direction that his business be continued, there is a liberal doctrine based on good faith which may protect a fiduciary from surcharge. In Casani's Estate, $342 \mathrm{~Pa} .468,21$ A.2d 59 (1941), the court held that the trustees would not be surcharged for retaining "non-legal" investments when retention represented ". . an honest exercise of judgment based on actual consideration of existing conditions." $I d$. at 473,21 A.2d at 61 . The issue in Casani was retention of "non-legal" investments rather than making new ones, as in the continuation of business problem. Perhaps the reasoning of Casani will be applied to the trustee who makes an investment in the good faith belief that it was within his power; but the scope of such an exception, if created, is uncertain. Reliance on any such dubious liberalization of fiduciary law by the courts would be ill-advised. The courts may refuse to approve the trustee's action, even when it was for the protection of the beneficiaries, if he had acted beyond his powers. $C f$. Kimberly's Estate, $227 \mathrm{~Pa}$. 405, 76 Atl. 99 (1910). Any trustee should be hesitant to accept a trust when he will be required to sustain the validity of so many investments by litigation. See Handling Businesses in Trust, 93 TRusts \& Estates 105 (1954). 
business. ${ }^{40}$ This power is limited to such advances as are necessary for the continuation of the business. ${ }^{41}$ The courts have upheld such advances where they were made to meet expenses in a business depression, ${ }^{42}$ to make repairs, ${ }^{43}$ or to preserve the estate from great loss. ${ }^{44}$ However, the fiduciary has been surcharged where he enlarged the facilities. ${ }^{45}$ Although these decisions are not direct authority for defining the fiduciary's power under a general authorization in the will, ${ }^{46}$ they would strongly suggest that the fiduciary has no power to use other principal of the estate to expand the business. For similar reasons, a general authorization to continue any business the testator is engaged in at his death may further limit the fiduciary's power to go into other lines of business. However, in many instances serving the interests of the beneficiaries may require switching to another product or service, taking on a new line or enlarging present facilities. ${ }^{47}$

Another source of capital for investment purposes is the net profit of the business itself. Ordinarily the trustee does not have the power to reinvest these amounts, ${ }^{48}$ in which case they would be distributed to the beneficiaries. In some instances, however, it may be more desirable to reinvest these funds rather than to obtain the money needed for the business from other parts of the principal of the estate, if the fiduciary can invade the entire estate for the benefit of the business. ${ }^{49}$ So long as the same persons are the ultimate beneficiaries of the business as well as other parts of the estate, it will likely be more expedient to satisfy the financial needs of a business out of its own profits rather than through liquidation of other assets which may be producing income themselves. Therefore, it would be a wise business move to place such a discretion in the hands of the fiduciary whenever feasible.

40. Sulzer's Estate, $323 \mathrm{~Pa} .1,185$ Atl. 793 (1936). If it is found that the testator intended that the business be continued only for purposes of liquidation, then such an investment would not seem proper. It is questionable whether such an investment would be approved where the business is continued for sale as a going concern.

41. Cf. Sulzer's Estate, supra note 40.

42. Donnelly's Estate, $246 \mathrm{~Pa}$. 308, 92 Atl. 306 (1914).

43. Parry's Estate, 244 Pa. 93, 90 Atl. 443 (1914).

44. Mustin's Estate, 188 Pa. 544, 41 Atl. 618 (1898); see Sulzer's Estate, $323 \mathrm{~Pa}$. 1, 185 Atl. 793 (1936).

45. Parry's Estate, 244 Pa. 93, 90 Atl. 443 (1914).

46. The cases arose in situations where the fiduciary was operating the business by consent of the beneficiaries rather than a general authorization.

47. Trachtman, Legal Aspects, 93 TRUSTs \& EsTaTes 106 (1954). Opinion seems split on whether or not a trustee would exercise such powers, but even those trustees who were doubtful as to whether they would use the power thought it was feasible to insert it to provide flexibility if needed.

48. Use of income is usually limited to current expenses. See James v. Echols, 183 Ark. 826, 39 S.W.2d 290 (1931) ; Bridge v. Bridge, 146 Mass. 373, 15 N.E. 899 (1888); Spencer v. Spencer, 219 N.Y. 459, 114 N.E. 849 (1916); 2 Scotr, TRUSTS 1260 (1930). Income is not permitted to be used for permanent improvements. Jones v. Harsha, 225 Mich. 416, 196 N.W. 624 (1923); Stevens v. Melcher, 152 N.Y. 551, 46 N.E. 965 (1897); see 2 Scorr, Trusts 1264 (1930).

49. See Sulzer's Estate, 323 Pa. 1, 185 Atl. 793 (1936). 


\section{Assets Subject to Liabilities of the Business}

If the assets of the entire estate are made available to be used in the business, either by express provision or by a general authorization, then the entire estate may be subjected to the risk of business failure..$^{50}$ This risk can be avoided by an express provision in the will which limits liability for all debts incurred in the fiduciary's operation of the business to the assets actually invested in the business. ${ }^{51}$ The express limitation prevents the creditor from relying on the assets of the entire estate, but in the absence of such a limiting clause, which would not be provided by a mere general authorization, whether the estate is or should be liable for these debts is a difficult point.

Although many states have limited liability for these debts to assets actually invested in the business or expressly committed to the business by the testator, ${ }^{52}$ the law in Pennsylvania would appear to be uncertain. The state supreme court has only faced the problem three times. In an 1864 case, Laughlin v. Lorenez's Administrator, ${ }^{53}$ the court clearly held that the estate is liable for debts incurred in the continuation of the business unless the testator has placed a limiting provision in the will or the articles of partnership. When the issue arose again in 1895, the lower court rejected the Laughlin rule and held that the estate would not be liable unless the testator manifested an intention to embark substantially his entire estate in the business. ${ }^{54}$ It thus adopted the rule of a majority of the states on this issue. 55 The supreme court affirmed the disposition in a per curiam opinion which rested on the ground that the executor had effectively renounced the interest of the estate in the business out of which the claimant's debt arose..$^{56}$ The last time the issue arose, the court again reiterated

50. See, e.g., Ferris v. Van Imgem, 110 Ga. 102, 35 S.E. 347 (1900); cf. Furst v. Armstrong, 202 Pa. 348, 51 Atl. 996 (1902); Waddell's Estate, $196 \mathrm{~Pa}$. 294, 46 Atl. 304 (1900).

51. In the case of a limiting clause in the partnership agreement, creditors are clearly limited to assets invested in the business. Wild v. Davenport, 48 N.J.L. 137, 7 Atl. 295 (Ct. Err. \& App. 1886); Stewart v. Robinson, 115 N.Y. 328, 22 N.E. 160 (1889) ; see Fuller, Partnership Agreements for Continnation of an Enterprise After the Death of a Partner, 50 Y ALE, L.J. 202, 210-13 (1940). It has been stated that the same rule applies to a limitation provided by will. Furst v. Armstrong, $202 \mathrm{~Pa}$. 348, 51 Atl. 996 (1902) ; Roessler's Estate, 5 Pa. Dist. 776 (Philadelphia County Orphans Ct. 1896); Laughlin v. Lorenz's Administrator, $48 \mathrm{~Pa} .275,283$ (1864) (dictum); see 2 WiLliams, ExECUTORS 1176 (12th ed. 1930); Toller, ExECUTORS $165-66$ (7th ed. 1838).

52. Smith v. Ayer, 101 U.S. 320 (1879); Moore v. McFall, 263 I11. 596, 105 N.E. 723 (1914); Laible v. Ferry, 32 N.J. Eq. 791 (Ct. Err. \& App. 1880); Columbus Watch Co. v. Hodenpyl, 135 N.Y. 430, 32 N.E. 239 (1892). An executor may be reimbursed for payments to creditors out of that part of the estate authorized by will to be employed in the business, and creditors may be paid out of property applicable to carrying on the trade. 2 WiLliAMs, EXEcurors 1174, 1176 (12th ed. 1930).

53. $48 \mathrm{~Pa} .275$ (1864).

54. As quoted in Wilcox v. Derickson, $168 \mathrm{~Pa}$.331, 334, 31 Atl. 1080 (1895).

55. See note 52 supra.

56. Wilcox v. Derickson, 168 Pa. 331, 31 Atl. 1080 (1895). 
the Laughlin rule. The case was Furst v. Armstrong, ${ }^{57}$ decided in 1902. The court was asked by one of the beneficiaries of a large estate to decree partition. It denied the petition on the ground that the general authorization of the testator that the executrix should continue his business was deemed to give her power to delay distributing all the assets of the estate, since these were made subject to the needs of the businesses by the testator's direction to continue them. Note, however, that the case does not necessarily provide that a creditor might have reached any part of the estate per the Laughlin rule; consistent with the holding could be an interpretation that the assets were available if the executrix needed them in one of the businesses, but that until she committed them they were not subject to the creditor's lien or levy.

From these few cases, it is apparent that the law in Pennsylvania is not firmly settled as to the extent of liability of the entire estate for debts incurred in the continuation of the business. Perhaps Pennsylvania could be convinced to accept the majority rule that the estate is liable only to the extent that the testator has indicated. At least two considerations are applicable. To hold the entire estate subject to business needs might result in an unreasonable delay in settling estates. ${ }^{58}$ The lower court in Wilcox, in advocating the majority rule, wrote of the difficulty that might arise if legacies or devises had to be recalled from the recipients to satisfy demands of the business. ${ }^{59}$ On the other hand, it is argued that the entire estate should be held liable since creditors are led to rely on the total assets unless expressly restricted. It may be not unreasonable to assume that creditors will know of the power to use all or part of the entire estate for the benefit of the business and consider that factor as an assurance of payment, much as creditors of an individually owned business recognize the full personal liability of the owner for debts of the business. This reliance theory of extension of credit is a manifestation of the ostensible ownership concept which is now largely discredited. Normally credit is extended initially on the basis of the purchaser's business prospects and credit history. ${ }^{60}$ Although the creditors may look to the value of specific assets of the estate as a secondary assurance of payment, it is doubtful if creditors consider the general assets of the estate which are not invested in the business. ${ }^{61}$ These are the factors that must be stressed if the court is to accept the limited liability rule for estates.

57. 202 Pa. 348, 51 Atl. 996 (1902).

58. See discussion of Furst v. Armstrong at note 57 supra.

59. See, e.g., Smith v. Ayer, 101 U.S. 320 (1879) ; Frey v. Eisenhardt, 116 Mich. 160, 74 N.W. 501 (1898); In the Matter of the Estate of A. C. Ennis, 96 Wash. 352, 165 Pac. 119 (1917); cf. Altheimer v. Hunter, 56 Ark. 159, 19 S.W. 496 (1892).

60. Jacoby \& SaUlnier, TerRM LENDing to Business 80-81 (1942); Schultz \& RatNHART, CREDTt aND Collection MANaGeneENT 245-54 (2d ed. 1954); Note, 104 U. PA. L. REv. 91, 92 (1955):

61. See Schultz \& RerNinArT, op. cit. supra note 60, at 63, 70-71, 72-73; Note, 104 U. PA. L. REv. 91, 92 (1955). The reports of Dun \& Bradstreet to creditors of partnerships and individuals contain no information on assets outside the business. 


\section{Authorization by CoURT}

In many states, the court may give the fiduciary power to operate the business or to cure defects in a general authorization. ${ }^{62}$ While some of these states enable the court to sanction continuation only for limited purposes, ${ }^{63}$ the Pennsylvania statute is more liberal. Under it, the order authorizing continuation may provide for: (1) continuation by the personal representative or trustee alone, or jointly with others, or as a corporation; (2) the extent of the liability of the estate or trust on any part thereof for the obligations incurred in the continuation of the business; (3) whether liabilities incurred in the business are chargeable solely to the part of the estate or trust set aside for such use or to the whole trust or estate; (4) the period of time the business may be conducted; (5) other regulations the court deems advisable. ${ }^{64}$

Like the testator's general authorization to continue the business, this is only a partial solution. Opposition to the petition leading to litigation will result in a loss of time and increased costs. Delay in obtaining the court's authorization may present the fiduciary with the risk of surcharge if he operates the business in the interim. But the major difficulty with the statute is that ". . . any party in interest may, at any time, petition the court to revoke or modify the order." 65 "The extent to which this subjects the operation of the business to the whims of beneficiaries and creditors is not known, but it is likely that this will prevent the trustee from conducting the business to the best of his ability. However, these limitations are necessary to protect the interests of beneficiaries; hence, such a statute cannot be wholly satisfactory to work out problems of continuing the business or method of correcting defects in the testator's will. ${ }^{66}$

\section{Illustrative Will Provision}

To avoid the legal problems -presented by a mere general authorization and the inadequacies of the statutory procedure, the most feasible solution is a properly drawn will provision. Although individual requirements will vary in each case, perhaps a model provision will give some indication of the method by which the problem may be solved.

Assume testator has a wife and a son and daughter, both minors. He is sole proprietor of a business buying and selling foods at wholesale. He has substantial capital investment in a warehouse, an office building

62. See, e.g., Cal. Prob. Code $\$ 572$ (1953); Fla. Stat. ANn. $\$ 733.08$ (1944); IOWA CODE ANN. $\$ 635.52$ (1950).

63. See, e.g., CoNN. GEN. StaT. $\$ 7039$ (1949) (completion of unfinished goods and sale of stock in the regular course of trade); GA. CODE ANN. \$113-1523 (1933) (sale as going concern during period of administration); MASS. GEN. LAWs c. 195, $\S 7$ (1932) (same).

64. PA. Stat. ANn. tit. 20, $\S 320.504,320.934$ (Purdon 1950). There does not appear to be any significant difference in the effect of $(2)$ and $(3)$, but both are listed in the statute.

65. Ibid.

66. Trachtman, stipra note 47. 
and trucks and employs drivers, salesmen, office and warehouse help. Testator wishes to leave his entire estate to his family and to have his business continued after his death for the benefit of his wife and children. Assume further that testator does not wish to incorporate the business prior to his death.

In drawing the provision for continuing the business, it might be advisable to leave it in trust. This has four significant advantages. The business could be placed in a non-qualifying trust ${ }^{67}$ for the life of the wife or in trust for the life of one or more beneficiaries other than the wife. This would avoid the imposition of any federal estate tax when it passes out of the trust to the remainderman. ${ }^{68}$ Secondly, the trustee can act as a caretaker of the business until a member of the family reaches maturity or gains the experience necessary to run the business. ${ }^{69}$ Thirdly, centralized control is achieved, whereas other methods of disposition may result in spreading control among numerous beneficiaries. A fourth significant consideration is that a trustee is amenable to the court for negligence and other misconduct. The importance of this can be determined by comparison to an outright gift to beneficiaries which might result in some of them acting to the detriment of others since they would be immune from the sanction of fiduciary liability. ${ }^{70}$

\section{Provision I.}

I give to my trustee the pozer to continue any business I may have at my death if he deems it advisable.

The authorization to continue the business should not be mandatory. Economic conditions may become unfavorable or the family situation may have changed so that continuation would not be warranted. Forcing a trustee to continue the business might result in total dissipation of assets and injury to those whom the testator seeks to protect. A further consideration is that the trustee chosen by the testator probably will not accept the trusteeship if continuation is mandatory. ${ }^{11}$ To insure that the person of the testator's choice will operate the business, the proposed trustee should be consulted at the time the will is drawn to insure his agreement with the powers given and to have the advantage of any practical suggestions he may have. ${ }^{2}$

67. This is a trust which does not qualify for the marital deduction. It differs from a marital deduction trust in that the wife gets only a life estate without a power to invade the corpus or a general power to appoint. If the wife had either of the foregoing, the assets in the trust would not be taxable to the husband's estate, but would be taxable to her estate. Assets in the non-qualifying trust are taxable to the husband's estate but might not be so taxable to the wife. INT. REv. CODE of 1954, §2056.

68. Id. $\S \S 2031,2056$.

$40,41$.

69. Tremayne, Estate Planning for the Man with a Business, 1955 WASH. U.L.Q.

70. See Hartman's Estate, $331 \mathrm{~Pa} .422,200$ Atl. 49 (1938).

71. Pfleiderer, When the Fiduciary Takes Over, 93 TRusrs \& EsTares 107 (1954).

72. See Handling Business in Trust, 93 Trusts \& EsTates 105 (1954). 


\section{Provision II.}

Said business to be continued for the life of my zerife and on her death to be continued for the life of the longest liver of my children. My trustee shall, however, have the power to discontinue the business at any time if he deems it advisable.

The period for which the business should be continued in trust will depend on the circumstances which demand continuation of the business. If the testator wishes to provide for his wife for life and had a minor son for whom he wishes the business to be held, the provision as to time would cover the life of the wife and the minority of the son, or more wisely, until the trustee believes that the son has gained sufficient experience to manage the business. However, the business might be held in trust for the lives of both the wife and son if the testator did not want to entrust the operation of the business to his son, or if he has more than one child and wishes the business to be run for their mutual benefit without the possibility of one child controlling it for himself. Obviously no standard formula for the duration of the trust can be devised.

\section{Provision III.}

In addition to powers granted by law, my trustee shall have the following powers, exercisable at discretion from time to time without court approval, with respect to both principal and accumulated income, and such pozers shall continue until the business is discontinued.

A. To incorporate the business at any time he thinks advisable, and once a form of business is chosen, he shall not be bound to continue in such form.

The power to incorporate provides a method by which the liability of the estate may be limited to those assets actually invested in the business. This power should be discretionary due to the varied circumstances which may confront the trustee, such as an undesirable corporate tax situation or limitations on incorporation under state law. Furthermore, the power to incorporate should be within the trustee's discretion at the inception of the enterprise or at any time during its continuation. No limitation as to the reason for incorporation should be set out. Two cases aptly illustrate the need of such provisions. In Scott's Estate, ${ }^{73}$ the testator provided that his business might be incorporated. The trustees decided to continue as a partnership because of excess profits taxes imposed on corporations. At a later date the trustees sought to incorporate, and the court held that they had exhausted the power to incorporate because of the original course they had taken. In Kimberly's Estate, ${ }^{74}$ the testator authorized the incorporation of one or more companies to carry on any business and to transfer to such corporation any property in the hands of the trustees. The court would 
not allow the trustees to form a holding company for the testator's securities even though the plan was "commendable" since the court believed the testator had meant only real property was to be conveyed to the corporation to be formed. Statutory provisions may cure these inadequacies, but its use is restricted to situations where there is no condition in the will and is subject to the general difficulties noted before. ${ }^{75}$

$B$. To accept in kind, retain and invest in any form of property without being limited to legal investments and without regard to any principle of diversification as to such property.

This provision removes any doubts as to the power to invest in "nonlegals," so that the trustee is freed from the risk of surcharge by mistaken reliance on implications based on special factual situations.

C. To invest any part of the principal of the residuary trust in the business for any purpose incident thereto, including but not limited to expansion, repairs, and entry into new fields of enterprise; if he finds it inadvisable to so use the principal, he may reinvest the business income.

This provision enables the trustee to invest the principal of the estate freely. Only when it is inadvisable to sell other income producing property for investment purposes may they divert the profits of the business from the hands of the beneficiaries to investment in the business. This power may be limited. In Pennsylvania, the power to invest income at one time was limited by the Estate Act of $1947,{ }^{76}$ which made accumulations void beyond the minority of the beneficiary.

$D$. (1) To appoint managers,

(2) To employ or discharge employees,

(3) To sell at public or private sale on credit or for cash,

(4) To borrow money and to mortgage or pledge any real or personal property,

(5) To compromise claims,

(6) To join in any merger, reorganization, voting trust plan, or other section of security holders.

These provisions are not meant to be exclusive. However, an enumeration of specific powers which may not fall within the general authority to operate the business enables the trustee to act without court approval or risk of surcharge in matters which are constantly coming before him. Tied to the provision for delegation, they insure an efficient operation of the business.

75. PA. STAt. Ann. tit. 20, $\$ 320.505,320.935$ (Purdon 1950); see text at p. 688 supra. However, consent of all interested parties is not required. See Commissioner's comment, PA. Stat. AnN. tit. 20, $\$ 320.505$ (Purdon 1950). 1030.

76. $I d$. $\S 301.3$. This section has been repealed. See PA. LAws 1955, No. 347, at 
E. To delegate duties with respect to all the foregoing powers; provided that the trustee in fact approve of and direct the exercise of all the powers herein provided except those provided in III B, D (2), (3), (5), and all other pozers necessary for the everyday operation of the business.

This provision forces the trustee to supervise the operation of the business, determine when it may be inadvisable to continue the business further, whether to incorporate or make major structural changes in the form of the business, whether it is advisable to expand or enter new lines of business, whether to invest principal or income or to borrow money, and to appoint the managers of the business. This protects the beneficiaries of the estate by insuring that major business decisions will be made by the trustee. On the other hand, it enables the trustee to delegate duties and powers so that the business can be effectively operated by the management in areas too trivial to demand the trustee's attention or in business functions requiring specialized knowledge or ability which can be performed by others more efficiently.

\section{Provision IV.}

These powers are to continue in any successor trustee named in the zeill.

Considering the wide powers granted, a court might believe that the appointed trustee was the only person contemplated by the testator to hold such powers. For this reason, all powers should expressly pass to a successor trustee. ${ }^{77}$

\section{Provision $V$.}

Only the assets actually invested in the business shall be liable for debts incurred in its operation.

This provision enables the business to be run without subjecting the assets of the entire estate to liability for debts incurred while the fiduciary operates the business. ${ }^{78}$ In provision III C, however, the power to use the entire principal of the estate in the business was given. From this a court might find an intention to embark the entire estate in the business, thus . subjecting the entire estate to the claims of creditors notwithstanding the limiting clause. Such a result would not seem to be justified. Although creditors might be misled by the fact that the trustee has the power to invest the principal of the entire estate, the express limitation should insure that creditors will not rely on any assets except those actually invested in the business so that this provision should control. However, to insure that the court will find that creditors were put on notice, it may be advisable to place the assets of the business in a separate trust with the power in the

77. Trachtman, supra note 47 ; see, e.g., Donaldson v. Allen, 182 Mo. 626, 81 S.W. 1151 (1904); Shoemaker's Appeal, 91 Pa. 134 (1879); see PA. STAт. ANN. tit. 20, $\S 320.947$ (Purdon 1950).

78. See pp. 686-87 supra. 
trustee to use the corpus of the residuary trust in the business. The corpus might be made available by loans to the business or by actual investment. The latter seems open to serious objections. Some form of limited partnership or corporation would have to be formed to admit the residuary trust. Otherwise, the trust would be acting as owner so that the vicious circle of limiting liability and advancing principal would appear again. The loan provision in the residuary trust would appear more feasible. The residuary trust would become a creditor, and the court would have difficulty in finding that both constitute a single trust.

\section{Conclusion}

It is recognized that each case will require a will provision tailored to meet its individual requirements, but it is submitted that a carefully drawn provision of broad scope is essential in every situation. Failure of the draftsman to draw such provisions can result only in a disastrous waste of time and money for his client's estate because of the limitations imposed by law on the powers of the fiduciary. Even with the broadest powers, there should be little fear of excesses on the part of the trustee. As has been stated by the Pennsylvania court, "... the measure of care and diligence required of a trustee is such as would be pursued by a man of ordinary prudence and skill in the management of his own estate." 79 Consistent with this high standard of conduct, power can be vested safely in the trustee to provide the greatest flexibility which is needed to attain the highest return possible for the trust.

79. Stong's Estate, 160 Pa. 13, 28 Atl. 480 (1894). 